


\section{LEGAL NOTICE}

This ceport was prepared os an eccount of Government sponsored work. Neither the United States, not the Commission, nor ony person octing an behalf of the Commission:

A. Mokes any warranty or representation, expressed or implied, with respect to the occurocy, completeness, or vsefulnass of the information contained in this repart, or that the use of any infarmalion. apparatus, method, or process disclesed in this report may not intringe privately owned rights: or:

B. Assumes any liabilities with respeet to the use of, or for damages resulting from the use of any informalion, opporatus, method, or pracess disclosed in this report.

As used in the obove. "person acting on beholf of the Commistion" includes any employen or contractor of the Commission, or employee of such sontractor, to the extant thas such employea or confractor of the Cornmission, or employte of such contractor preparas, disseminates, or proyides access to, any information pursuant to his employment of contract with the Commiasion, or his employment with such contractor.

\section{PACIFIC NORTHWEST LABORATORY \\ RCHLAND. WASHINGTON \\ operated by}

BATTELLE MEMORIAL INSTITUTE

for the

UNITED STATES ATOMIC ENERGY COMMISSION UNDER CONTRACT AT(45-1)-1BSO 


\section{9}

BNWL- 755

UC-30, Reactor

Technology

INSULATION OF THE FFTF CLOSED LOOP TUBES

By

G. R. Sawtelle

Engineering Mechanics and Materials Section

November 1968

BATTELLE MEMORIAL INSTITUTE PACIFIC NORTHWEST LABORATORY RICHLAND, WASHINGTON 
BNWL- 755

Printed in the United States of America Available from

Clearinghouse for Federal Scientific and Technical Information National Bureau of Standards, U.S. Department of Commerce Springfield, Virginia 22151

Price: Printed Copy $\$ 3.00 ;$ Microfiche $\$ 0.65$ 


\title{
INSULATION OF THE FFTF CLOSED LOOP TUBES
}

\author{
G. R. Sawtelle
}

\section{ABSTRACT}

The FFTF closed loop tubes will operate in liquid sodium at a temperature level of up to $1400{ }^{\circ} \mathrm{F}$ with a wall temperature difference of $400^{\circ} \mathrm{F}$. Methods of providing insulation to reduce heat transfer and thermal stresses to acceptable levels are evaluated. A twin-wall tube was chosen to provide an annular gap, isolated from the sodium, for the insulating materials, and to provide a gas circulation channel for controlling the thermal conductivity of the tube wall. 


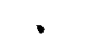

,

,

, 


\section{TABLE OF CONTENTS}

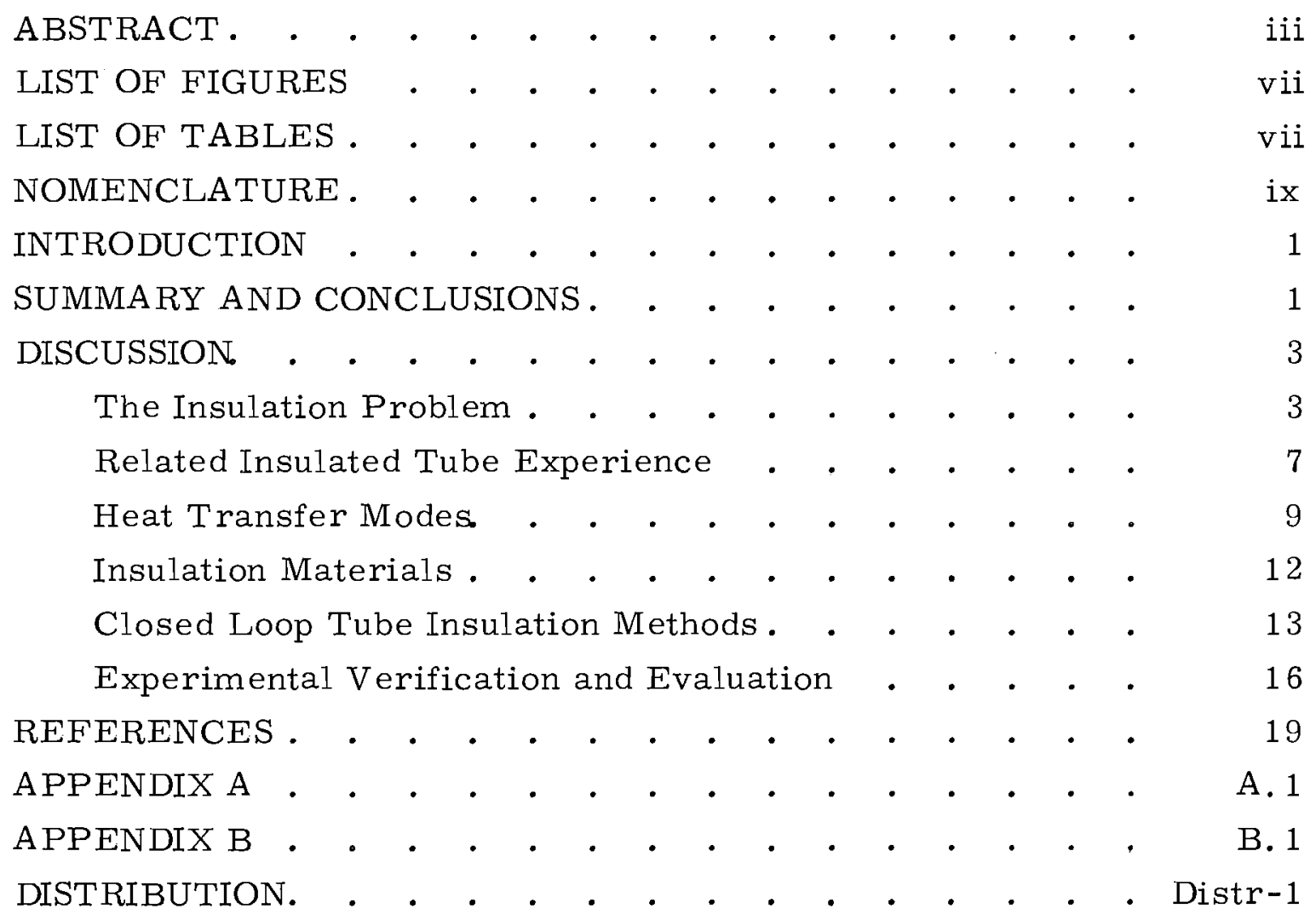




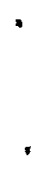

, $\checkmark$ 


\section{LIST OF FIGURES}

1. A Schematic of Closed Loop Re-entrant and U-Tube Configurations with Typical Operating Temperatures

2. Thermal Conductivity Versus Temperature for Noble Gases and Air

3. Effective Thermal Conductivity Versus Temperature for Various Surface Emittance

4. Thermal Conductivity Versus Temperature for Several Insulation Gap Fillers

B. 1. Thermal Conductivity Versus Temperature for Several Solid Insulant Materials

B. 3

\section{LIST OF TABLES}

I Operating Conditions Relevant to the Closed Loop Tubes

A. 1 Related Insulated Tube Studies Data

A, 3

B. 1 Properties of Various Commercially Available Insulation Materials Applicable to the Closed Loop Tubes

B. 2 


\section{NOMENCLATURE}
A Area
E Elastic modulus
F Grey body shape factor
$\mathrm{n} \quad$ Number of thermal shields
Qr Net heat transfer rate
$\mathrm{S}_{\mathrm{t}} \quad$ Axial and tangentral thermal stress
$\mathrm{T}$ Surface temperature
$\triangle \mathrm{T} \quad$ Temperature difference across the tube wall
$\alpha \quad$ Coefficient of linear thermal expansion
$\varepsilon \quad$ Total emittance
$\checkmark \quad$ Poisson's ratio
$\sigma \quad$ Stefan-Boltzmann constant 


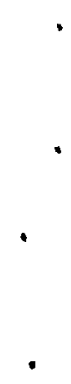

$+$

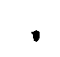




\title{
INSULATION OF THE FFTF CLOSED LOOP TUBES
}

\author{
G. R. Sawtelle \\ INTRODUCTION
}

The Fast Flux Test Facility (FFTF) will be used to investigate the behavior of materials in typical and extreme conditions of fast neutron environments that will be encountered in future fast breeder reactors. The principal component of the facility is the fast test reactor (FTR) which is designed to meet the process and handling requirements of multiple closed test loops.

The closed test loops will provide a highly instrumented, controlled, isolated (except for neutron flux) system for testing coolant, fuels, and material specimens in an environment different from that found elsewhere in the reactor core. Each closed loop includes equipment for heat removal, purification, and circulation of the coolant, and instrumentation for operational control, safety, and test data collection. The independence of each loop makes possible the control of the temperature level and coolant flow rate, and hence the temperature increase across the test section. Furthermore, since the system is isolated, it will be possible to investigate the effect of contaminated sodium, other liquid coolants, and possibly gaseous coolants.

The in-pile closed loop tube walls will be exposed to large temperature differences during startup, running, and shutdown operations. In order to maintain isolation or independence of the closed loops, sufficient thermal insulation must be provided to limit or control the effect of the heat transfer between the closed loops and the bulk reactor coolant. This report is an initial review and evaluation of insulation methods for the closed loop tubes.

\section{SUMMARY AND CONCLUSIONS}

Both the re-entrant and the U-tube design concepts being actively considered for the FFTF closed loop tubes require that considerable insulating capability be incorporated into a thin wall structure 
in a minimum thickness. Achieving the required insulation is complicated by many factors:

- Operating temperatures will be up to $1400^{\circ} \mathrm{F}$.

- Temperature differences of up to $400^{\circ} \mathrm{F}$ or more across the tube walls must be maintained.

- The structure must be reliable, particularly with respect to thermal stresses associated with large temperature differences.

- The insulation must be compatible with the neutron environment and it should be compatible with sodium or other liquid metals.

- Increasing the thermal conductivity of the insulant during a closed loop coolant blockage is necessary to prevent closed loop tube failure.

- At least part of the tube structure will be of stainless steel, which has a relatively high thermal expansion coefficient.

The insulation problem was considered from the viewpoint of related tube experience, insulants available, and basic heat transfer considerations, with the effects of gamma-heating omitted. A twin-wall tube with an annular insulation gap utilizing vacuum, inert gas, inert gas mixtures, or inert gas and low density solid fiberous or metallic foil material for the insulant appears to be the most desirable concept. With this concept, for example, a $1 / 8 \mathrm{in}$. helium gas gap with oxidized internal surfaces which is a relatively poor insulation, most of the temperature difference is within the insulation gap, and thus acceptable tube wall thermal stresses are maintained. However, the difference in thermal expansion between the outer and inner tube walls requires a slip joint, bellows, or some other accommodation at one end of the tube. The inner tube wall surface conditions are important; heat transfer by a $1 / 8 \mathrm{in}$. argon gas gap at a mean temperature of $1200{ }^{\circ} \mathrm{F}$ is theoretically $67 \%$ less for polished surfaces (emittance $30 \%$ ) than for oxidized surfaces (emittance $80 \%$ ).

Selection of the insulating gap filler offers several alternatives. A vacuum of 1 Torr or less would effectively reduce the portion of heat transfer due to gas conduction, which would be appreciable in the case 
of helium, and it would be adaptable to rapid coolant flooding for increas ing heat transfer. Expensive provisions might be required to maintain the vacuum. The use of a recirculating inert gas or gas mixture as an insulant appears attractive since heat transfer could be controlled to some extent during normal operations by varying the gas mixture and/or by coolant flooding; gas recirculation and purification equipment would be needed. A solid insulant such as a ceramic in a fiberous form or a metallic foil insulation could be combined with a stagnant or recirculating gas scheme for effective insulation. The solids may maintain the gap spacing between the inner and outer tubes, but they would also incur gamma heating.

The twin wall tube using an annular insulation gap requires development work in the following areas for final design:

- Determination of the insulation effectiveness provided by the selected structure under various simulated reactor operating conditions, gas (or vacuum) quality, and tube surface emissivity ranges.

- Experimental verification of structural adequacy, particularly in maintaining a uniform insulating gap by spacers or other means and avoiding hot spots that could produce tube distortion or excessive thermal stresses.

- Experimental verification of slip joints, bellows, or other designs to accommodate relative movement between the inner and outer tube walls and spacers (including limiting stresses, galling, fretting, etc.).

- Prototype closed loop tube assembly testing.

\section{DISCUSSION}

\section{THE INSULATION PROBLEM}

The most recent closed loop tube conceptual designs consist of a U-tube and a re-entrant tube configuration (Figure 1). Development work, including this insulation study, has been concentrated on the re-entrant tube concept. However, the U-tube configuration could be selected for initial or future experiments and will present similar insulation problems. 


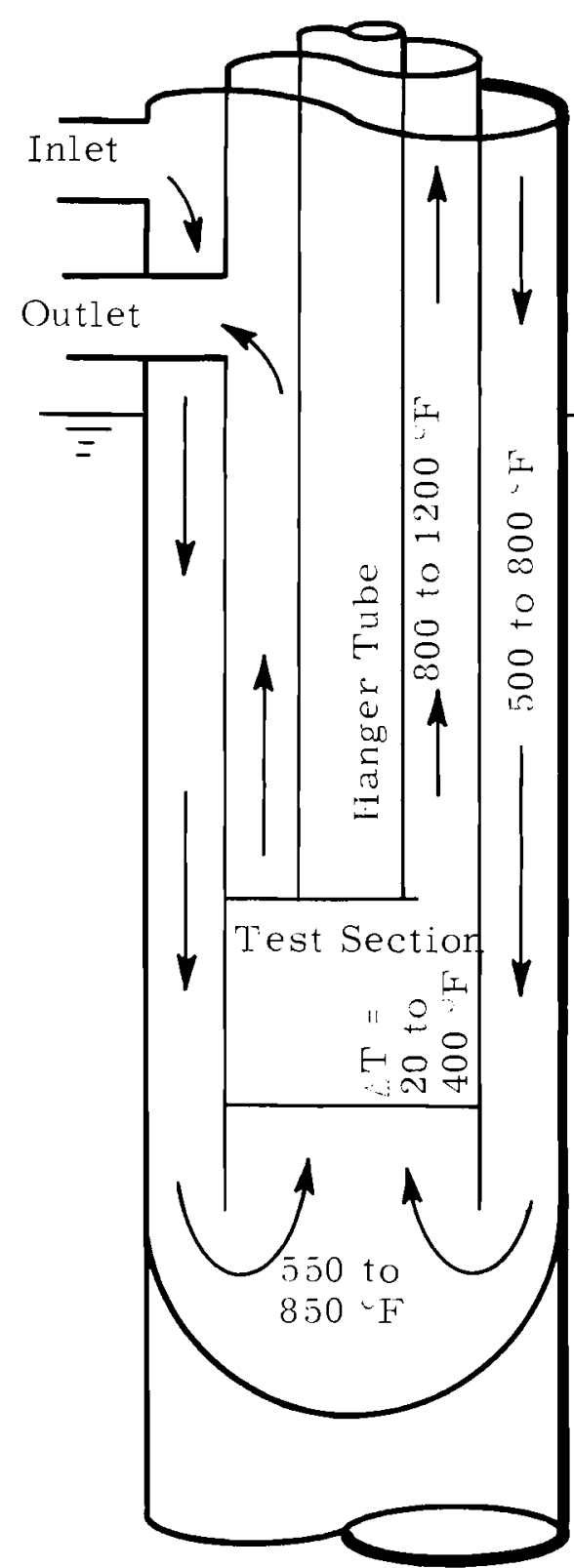

Qe-entrant Tube
800 to $1200^{\circ} \mathrm{F} \quad 500$ to $800^{\circ} \mathrm{F}$ Outlet Inlet

350 to $500 \cdot \mathrm{F}$ Cover Gas

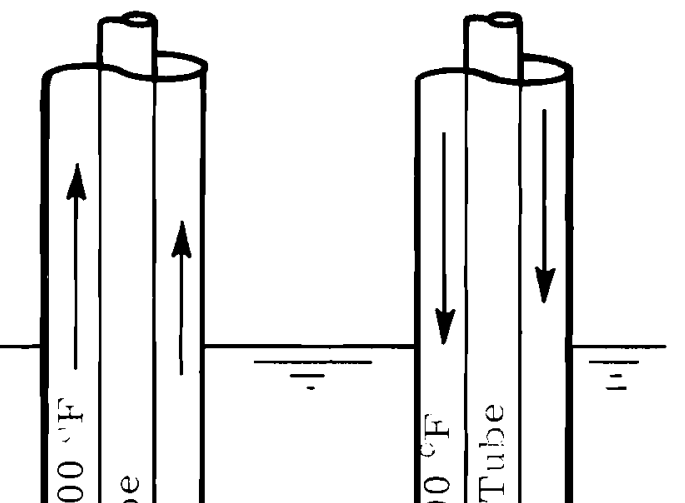

Sodium

800 to $1000^{\prime} \mathrm{F}$

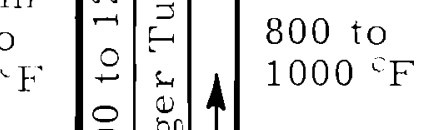

E

$\begin{array}{cc}0 & 4 \\ 0 & 0 \\ 0 & 0\end{array}$

:
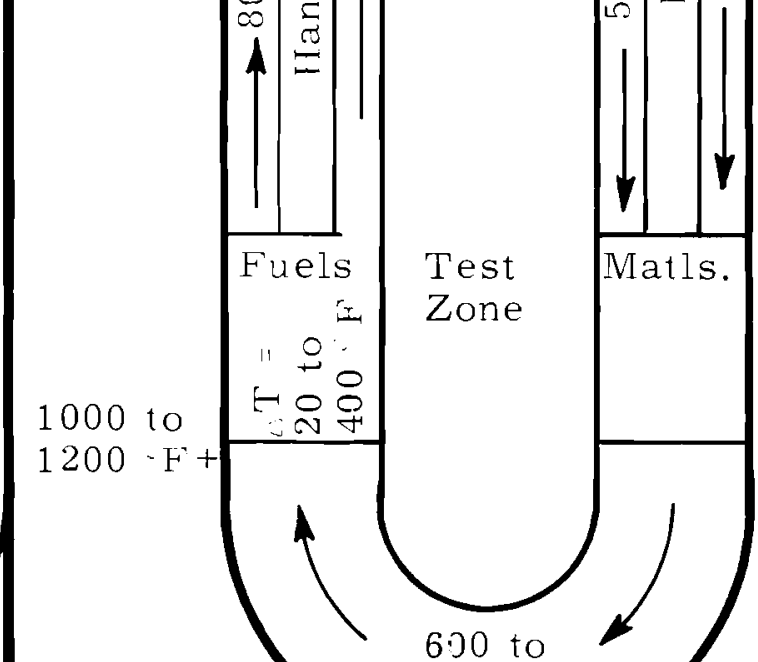

550 to

$800 \cdot \mathrm{F}$
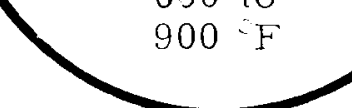

I-Tuhe

FIGURE 1. A Schematic of Closed Loop Re-entrant and U-Tube Configurations with Typical Operating Temperatures 
The temperature profiles of the closed loop tubes, the coolant, and the surrounding sodium will present severe operating conditions. Closed loop tube walls must provide for temperature differences across the wall of $400^{\circ} \mathrm{F}$ or more at loop operating temperatures in excess of $1200^{\circ} \mathrm{F} . *(1)$ Furthermore, since the closed loop test space is small, the insulation for the closed loop tube wall must be provided in a minimum of space to allow the largest possible test section. The tube configurations and these operating conditions, particularly the expected temperature gradients, establish the requirements for insulation to reduce heat transfer and provide a closed loop test system thermally isolated from the reactor sodium.

The design must avoid excessive thermal stresses that can result from the difference in thermal expansion across a tube wall due to the large temperature gradient. The axial and tangential thermal stress level $\left(S_{t}\right)$ in a thin tube from a wall with a temperature difference $\Delta \mathrm{T}$ is given by

$$
S_{t}=\frac{1}{2} \frac{E \alpha \Delta T}{(1-\nu)}
$$

where $\alpha$ is the coefficient of linear thermal expansion, $E$ is the modulus of elasticity, $v$ is Poisson's ratio, and a thin tube is one in which the ratio of wall thickness to radius is much less than unity. (2) As pointed out by Aungst, ${ }^{(3)}$ for a $\Delta \mathrm{T}$ of $500^{\circ} \mathrm{F}$, the hoop stress will be about 50,000 psi or nearly 5 times the yield stress of 304 SS at a reactor operating temperature of $1200^{\circ} \mathrm{F}$. Townsend ${ }^{(4)}$ suggests that the maximum allowable temperature difference in the tube wall should be. less than $50^{\circ} \mathrm{F}$.

* See Table I and Figure 1 for additional operating conditions. 
TABLE I. Operating Conditions Relevant to the Closed Loop Tubes

Reactor Core Conditions

Coolant Inlet Temperature

Coolant Outlet Temperature

Coolant Inlet Pressure

Coolant Outlet Pressure

Cover Gas Pressure

Cover Gas Temperature

Temperature Above Nozzles

$$
\begin{aligned}
& 550 \text { to } 800^{\circ} \mathrm{F} \\
& 800 \text { to } 1000^{\circ} \mathrm{F} \\
& 120 \text { to } 160 \mathrm{psig} \\
& 0 \text { to } 40 \mathrm{psig} \\
& <10 \text { in. of } \mathrm{H}_{2} \mathrm{O} \\
& 350 \text { to } 500^{\circ} \mathrm{F} \\
& 200 \text { to } 300^{\circ} \mathrm{F}
\end{aligned}
$$

\section{Closed Loop Tube Conditions}

Coolant Inlet Temperature

Coolant Outlet Temperature

Coolant Inlet Pressure

Coolant Outlet Pressure

Coolant Flow Rate ${ }_{\text {Test Section Temperature }}^{(a)}$

Test Section $\Delta \mathrm{T}$

Test Section $\Delta \mathrm{P}$

Maximum Test Diameter

Maximum Test Length

Maximum Test Length below Core

Total Power(a)

Flux

$$
\begin{aligned}
& 500 \text { to } 1100{ }^{\circ} \mathrm{F} \\
& 800 \text { to } 1200 \circ \mathrm{F} \\
& 20 \text { to } 150 \mathrm{psig} \\
& 20 \text { to } 50 \mathrm{psig} \\
& 70 \text { to } 600 \mathrm{gpm} \\
& 1600{ }^{\circ} \mathrm{F} \\
& 20 \text { to } 400^{\circ} \mathrm{F} \\
& 1 \text { to } 130 \mathrm{psi} \\
& 31 / 2 \text { to } 4 \mathrm{in} . \\
& 15 \mathrm{ft} \\
& 2 \text { to } 31 / 2 \mathrm{ft} \\
& 0.6 \text { to } 5 \mathrm{MW} \\
& 0.5 \text { to } 0.6 \mathrm{x} 10^{16} \\
& \mathrm{n} / \mathrm{cm}^{2} / \mathrm{sec}
\end{aligned}
$$

(a) Power and temperature limits determined by testing requirements and material limitations.

The gaseous or solid insulants must be compatible with the environment including the following:

- Flux levels to $0.6 \times 10^{16} \mathrm{n} / \mathrm{cm}^{2} / \mathrm{sec}$, total accumulated flux, and gamma heating.

- Temperatures to $1400 \mathrm{~F}$, thermal cycling, and thermal shock.

- Tube structural materials and other insulants that are present.

- Sodium or other liquid metal coolants (possibly for only short periods of time).

- Vibration. 
During normal operating conditions, maximum thermal isolation of the loop system from the reactor sodium is desired; the isolation is to be provided by minimizing the heat transfer rate. There may be conditions, however, such as a scram situation caused by a closed loop system failure, when it will be necessary to remove heat from the closed loop system. It may therefore be necessary to increase the thermal conductivity and dump the heat generated in the loop to the bulk coolant, or provide an additional heat removal channel, or do both. The result is that a controllable thermal conductivity concept deserves some consideration.

RELATED INSU LATED TUBE EXPERIENCE

A literature survey on insulated tubes for reactor service was made. Solid insulated tube studies have been conducted for the AECL in connection with the heavy water and organic cooled reactor programs. $(5-8)$ These solid insulated tubes consisted of a stress tube with an external or internal insulation and liner tube. The stress tube and liner tube were rigidly connected at each end either by a rolled joint construction or a mechanical clamp mechanism without a slip joint, bellows, or other arrangements to allow for different wall expansion. They have performed with only limited success for several cycles at limited pressure and temperature levels. Since this concept could provide a tube construction with a minimum wall thickness, the applicability to a 304 SS system deserves consideration.

Using EaiT/yield stress as a modeling parameter for a first approximation in comparing operating stress, 304 SS would have an expected stress $(\mathrm{E} \alpha \wedge \mathrm{T})$ to yield stress ratio from 2.4 to 27 times larger than the tubes examined, and therefore, the rigid connection concept appears questionable for 304 SS.

The Min $-\mathrm{K}^{*}$ insulation used in the aforementioned tubes was chosen as an insulant because of its desirable properties, including

* Min-K is the trade name of a fiberous silica-asbestos insulation material manufactured by the Johns Manville Company. 
relatively low neutron capture cross section, and high temperature, low thermal conductivity characteristics. Irradiation tests have shown Min-K to be stable to at least $3 \times 10^{20} \mathrm{n} / \mathrm{cm}^{2}(\mathrm{E}>1 \mathrm{MeV})$. Additional information necessary for comparison and determination of applicability of these studies to the closed loops is indicated in Appendix A.

A report ${ }^{(9)}$ describing a French patent on a pressure tube, fuel cartridge, moderator-insulant concept has been reviewed. In this concept, the tube is designed to allow a portion of the coolant to pass between the pressure tube and the insulating jacket, thereby reducing the temperature and increasing the strength properties of the pressure tube. However, the insulating jacket is subjected to a large temperature difference which may only be acceptable to graphite that also serves as a moderator in this application.

A German patent ${ }^{(10)}$ of an end connection for a power tube of a nuclear reactor which consists of an inner pressure tube and a concentric jacket tube has been reviewed. The annular space between the tubes provides a passage for coolant flow. This connection is designed to allow for differential thermal expansion by providing a suction-seal mechanism at the joints. The connection consists of many joints, seals, and annular passages, and it does not appear to be of practical application for the closed loop tubes.

The PRTR incorporates a gas annulus concept. (11) The PRTR fuel channels are insulated from the calandria tubes by a $0.270 \mathrm{in}$. helium annulus. The helium is essentially stagnant since circulation is at a rate just sufficient for leak detection. The operating temperature of the insulating annulus is in the order of $575^{\circ} \mathrm{F}$ maximum tube temperature with a temperature drop of less than $275^{\circ} \mathrm{F}$.

Insulation tests were conducted at Oak Ridge National Laboratory (ORNL) and Orenda Engines Limited (OEL) ${ }^{(12)}$ to define the operating characteristics of insulation configurations that would best suit the gascooled in-pile loops (ORR No. 1, ORR No. 2) in the Oak Ridge Research 
Reactor and the Experimental Gas-Cooled Reactor. Tests were conducted with helium and carbon dioxide at temperatures up to $1000{ }^{\circ} \mathrm{F}$ and pressures to $1000 \mathrm{psig}$, in a $5 \mathrm{ft}$ vertical annulus, 0.275 in. to $1.5 \mathrm{in}$. thick. The chief insulation method tested was a spirally wrapped foil in which $1 / 8$ in. spacing between adjacent foil turns was maintained by strips of corrugated sheet metal 1 in. wide. Results from this arrangement in an atmosphere of helium have shown gross effective thermal conductivity values to be approximately $150 \%$ to $200 \%$ of the values for the gas itself. Tests at ORNL indicated that the specimen composed of spirally wrapped shim stock spaced by intermittent corrugated strips had the best insulating characteristics of the configurations tested. It exceeded the performance of the stainless steel wool by $50 \%$ and was $10 \%$ superior to the insulation using sandwiched, corrugated foil.

The ATR high temperature helium loop model ${ }^{(13)}$ at BNW utilizes metallic foil (Inconel) insulation in the test sections. The loop contains two test sections, one horizontal and one vertical into which the ultra-pure helium (less than $1 \mathrm{ppm}$ ) flows at a maximum inlet temperature of $2100^{\circ} \mathrm{F}$ and $1800^{\circ} \mathrm{F}$ respectively. Helium is allowed to flow between the foil layers which are wrapped 30 layers per inch to a thickness of $3 \mathrm{in}$. in the horizontal and $11 / 4 \mathrm{in}$. in the vertical test section.

Both Westinghouse ${ }^{(14)}$ and Phillips Petroleum Company ${ }^{(15)}$ have suggested in their alternate concept studies, a twin-walled tube with a helium gas jacket as the insulation concept.

The literature survey for articles on insulated tube concepts, and operating or experimental results, yielded little information. Since the FFTF will be operating at conditions more severe than previous reactor facilities, the applicability of those reports cited is limited. HEAT TRANSFER MODES

Heat transfer occurring in vacuum, solids, liquids, gas, and circulating gas or liquids (as seems pertinent to the closed loop tube insulation problem) is discussed in this section. In a thermally perfect 
vacuum (one in which gas conduction is negligible) heat is transferred by thermal radiation. The net rate of heat transfer by radiation $\mathrm{Qr}$ is given by

$$
\mathrm{Qr}=\mathrm{F} \sigma \mathrm{A}\left(\mathrm{T}_{\mathrm{H}}^{4}-\mathrm{T}_{\mathrm{C}}^{4}\right)
$$

where $F$ is a gray-body shape factor which compensates for geometry and departure of the surface from black-body conditions. Since the annular space is small compared to the mean diameter, the gray-body shape factor for two parallel flat plates with the same emittance $(\approx)$ will be a good approximation and reduces to ${ }^{(16)}$

$$
F=\frac{1}{2 / \varepsilon-1}
$$

For a given operating temperature and gap width, the rate of heat transfer can be reduced only by changing the emittance. Emittance for stainless steel surfaces ranges from about $80 \%$ (oxidized) to about $22 \%{ }^{(16,17)}$ for a highly polished surface. Thus, a highly polished surface can reduce radiation heat transfer to less than $1 / 4$ that of an oxidized surface.

A narrow gas-filled insulation gap will contribute to heat transfer by thermal radiation and gas conduction. Convection heat transfer is negligible for narrow annular gas gaps at moderate pressures. (18) That is, it is negligible when the Grashop-Prandtl number product is less than 3000 , which is the critical value for suppression of natural convection. (12) Furthermore, radiation heat transfer will be the same order of magnitude as in a vacuum gap since gas absorption is minimal in a narrow gap.

Gas conduction will contribute to heat transfer in all insulation gaps where the pressures are not severely reduced. That is, the thermal conductivity of gases is nearly independent of pressure down to about 1 Torr, (approximately $1 \mathrm{~mm} \mathrm{Hg}$ ). Between 1 and $1 \times 10^{-4}$ Torr, the thermal conductivity goes from a value that is very close to its value at atmospheric pressure to nearly zero. (19) In addition, for a temperature range of a few hundred degrees, the thermal conductivity of gases increases slightly (see Figure 2). 


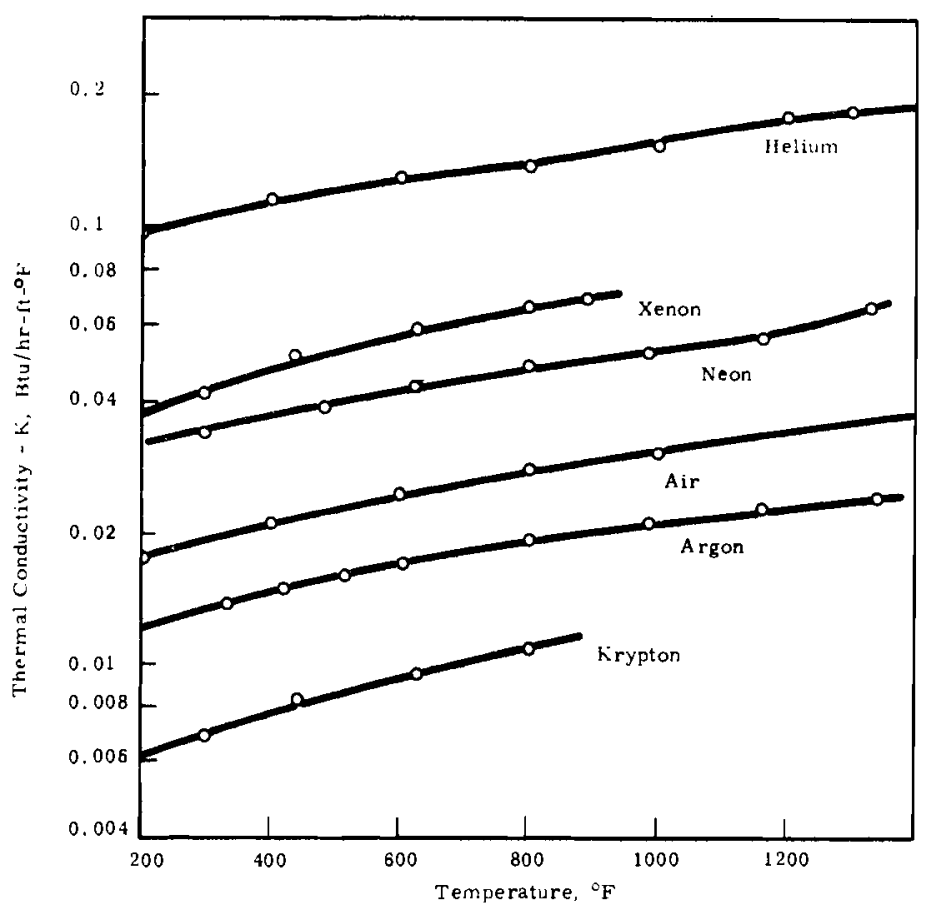

FIGURE 2. Thermal Conductivity Versus Temperature for Noble Gases and Air

The major modes of heat transfer in a liquid filled insulation gap will be by conduction and convection. Thermal conduction is about an order of magnitude larger in liquids ${ }^{(16)}$ than in gases, and convection currents will also be more evident since the Grashop-Prandtl number product will be much larger. The effectiveness of a liquid as an insulator is dependent on the thermal resistance of the film coefficient produced at the liquid solid interface.

Circulating fluids could provide an insulation method with a large thermal conductivity range by changing the flow rate and/or the fluid or fluid mixture. The flowing insulant method differs from other forms of insulation in that the closed loop looses heat to the circulating fluid, thereby reducing the amount of heat absorbed by the bulk coolant. Furthermore, temperature gradients in the tube walls will be larger than for stagnant fluids. Hence, the effective thermal conductivity must be limited to some maximum value corresponding to a maximum acceptable thermal stress level in each wall. 
The dominating modes of heat transfer in solids depends on the particular material and its characteristics including density and geometry. There are several types of insulant materials commercially available in the form of fibers, ceramics, powders, and foils.

Fiberous insulating materials reduce thermal radiation and convection, the effectiveness of which depends not only on the thermal conductivity of the material but also on the thermal properties of the interstitial gas and the material density. Metallic foils are used as thermal radiation shields, and theoretically reduce heat transfer by a factor of $1 /(1+n)$, where $n$ is the number of shields. These foils also reduce convection currents, provide additional solid-liquid interfaces in a liquid environment, and contribute to metallic conduction. Ceramics and powders are quite dense, and the principal heat transfer mode is solid conduction, although gas conduction is appreciable in the coarse powders and ceramics that have large gas entrapment cavities.

\section{INSULATION MATERIALS}

There is a variety of insulation materials available for use in the closed loop tubes. The noble gases are of interest because of their inert or stable character around other materials such as stainless steels at high temperatures. The thermal-conductivity of the noble gases as a function of temperature are shown in Figure 2. Since krypton has the lowest conductivity of the noble gases it would be preferred. However, krypton like xenon is not abundant. This leaves argon, neon, and helium, which increase in conductivity and decrease in abundance in that order.

Liquids do not appear to be good candidates for insulation because of their poor insulating quality relative to gases, because of their density (gamma heating potential), and because of their general incompatibility with the environment.

Solid materials are available in the form of fibers, solids (either blown or particulate), and metallic heat shields. The fiber insulation materials are most desirable because of their low density and conductivity properties. Solids and metallic heat shields or foils tend to be better 
conductors than fibers although foil materials may help reduce radiation significantly. Solid ceramics are quite dense and brittle, and will significantly contribute to gamma-heating. The thermal conductivity of selected solid insulants is presented in Appendix B.

CLOSED LOOP TUBE INSULATION METHODS

Single-wall and twin-wall closed loop tubes have been considered. In the single-wall tube, thermal insulation can be provided by attaching a low thermal conductivity layer to the tube wall. This can be provided by such arrangements as fins or baffles or a canned or attached insulation. The fins or baffles must not introduce excessive stresses in the tube, nor should they seriously disturb the flowing sodium coolant. The attached insulant materials must meet the following requirements:

- They must possess thermal expansion characteristics compatible with stainless steel such that thermal stresses will be acceptable to both the insulant and the tube wall.

- Since they are exposed to the sodium coolant they must be compatible with sodium and be able to withstand vibrations and shear stresses induced by the high velocity sodium.

The twin-walled tube concept provides an annular space isolated from the coolant for insertion of insulating materials. The possible insulation gap fillers are vacuum, stagnant gases, stagnant liquid, circulating gases or liquids, solids, or the possible combinations. The twin-walled concept will require some form of spacers to maintain a uniform gap width, and a slip joint or bellows to allow for differential expansion of the two walls.

The single-wall concept appears to be inadequate because there is no known material available that has a low thermal conductivity and a thermal expansion compatible with 304 SS, and because the re is no apparent alternate method of removing heat from the loop. Baffles may provide enough thermal resistance to limit thermal stresses, but they would also induce coolant flow disturbances and perhaps local tube wall stress problems. 
The double-wall insulation gap concept appears to be versatile and desirable. The proper selection of a gap filler will provide a relatively low thermal conductivity insulated wall. The double wall configuration will require a slip joint or bellows to limit stresses due to differential thermal expansion, and some form of spacers to maintain gap width. Furthermore, this concept provides a method for circulating a gas or liquid through the annular space. Although the limit on wall temperature difference appears to be severe, a heat transfer analysis of a twin-walled tube indicates that a $1 / 8$ in. helium gas gap will be sufficient to limit the temperature difference $(\Delta T)$ in each wall (and hence the thermal stresses) to an acceptable level.

A good insulation gap filler appears to be a low thermal conducitivity gas or vacuum pumped space, with or without a solid insulant material. A vacuum will reduce the gas conductivity; however, the amount of reduction in thermal conductivity may not warrant the equipment required to maintain a vacuum. (Recall that a minimum pressure of 1 Torr must be obtained before gas conduction is reduced.) As suggested earlier, argon is a desirable gas because of its low thermal conductivity and abundance. Argon may be used as a cover gas and would therefore appear to be acceptable from a nuclear compatibility standpoint. However, in the insulation gap, the gas will be exposed to a much higher neutron environment.

A gas circulating system may be required, regardless of the gas used, to filter the excess radioactive gases and other impurities. This system could also provide the means for controlling the thermal conductivity of the insulation gap and/or for a backup heat removal system.

A plain gas gap without solid materials will require polished radiating surfaces to reduce thermal radiation. The relative contribution to heat transfer by gas conduction and radiation at various emissivity values is shown in Figure 3 . The relative contribution of gas conduction and thermal radiation indicates that a vacuum pressure would appreciably reduce the thermal conductivity in a helium gap, but would have limited effect in an argon gap even if the emissivity is as low as $30 \%$. 


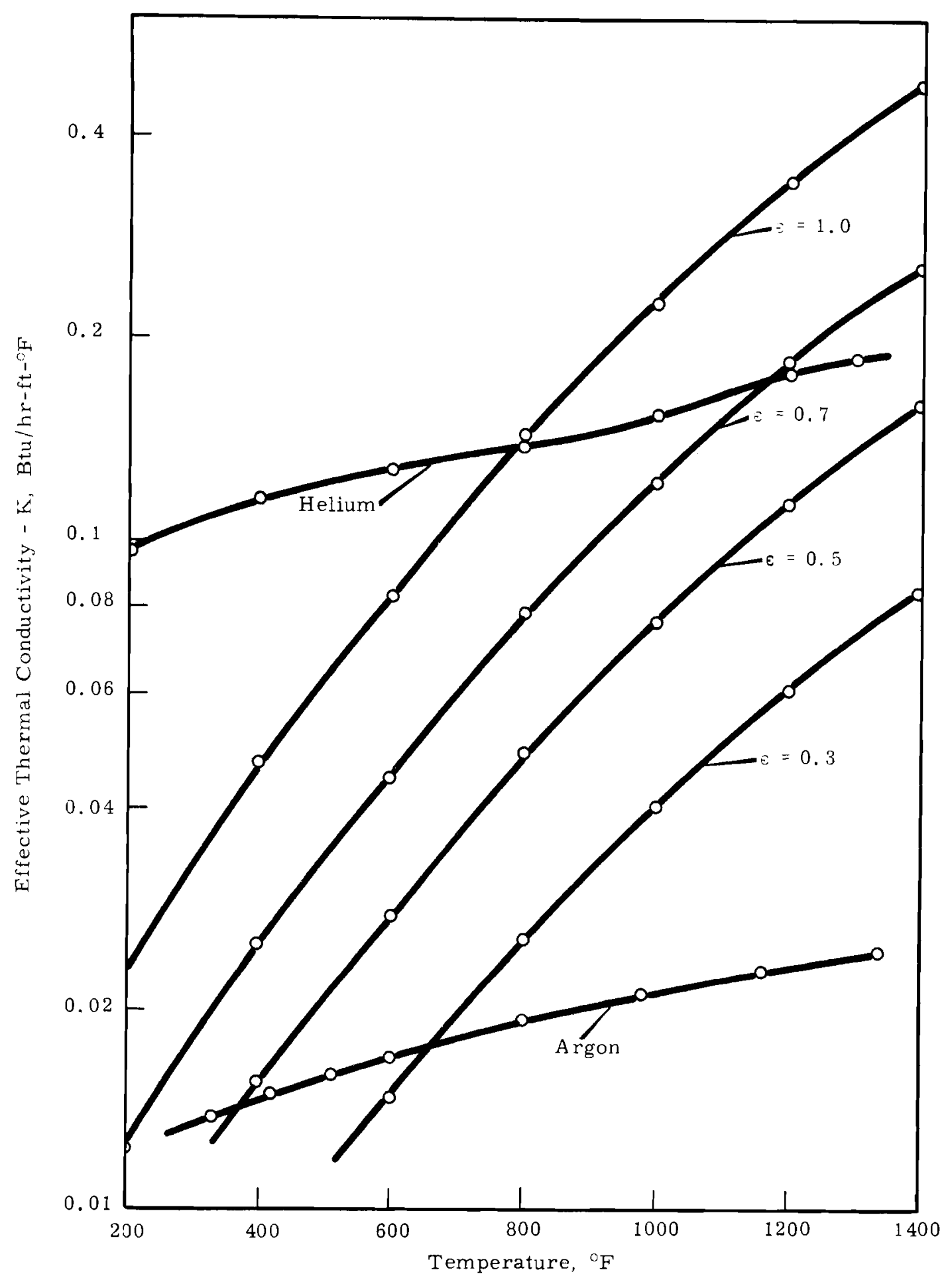

FIGURE 3. Effective Thermal Conductivity Versus Temperature for Various Surface Emittance. (The effective thermal conductivity is based on and only applies to a $1 / 8$ in. gap width) 
The use of solid materials in the insulation gap will eliminate the need for polished radiating surfaces with the possible exception of metallic foil fillers. The total thermal conductivity versus temperature for several combinations of gap fillers is indicated in Figure 4. Although the contribution of thermal conductivity due to spacers has not been included, it is expected that the added heat conduction will not seriously affect the choice of insulation materials.

If the gas conduction is minimal, only the Min-K insulation material of those commercial insulants considered appears to provide a lower thermal conductivity than a gas gap. Solid materials will also reduce the rate at which a gas can be circulated through the annular gap for a given pressure drop, and therefore may not be acceptable. However, if Min-K or some other solid material could provide sufficient strength to maintain gap width and distribute the load between the tube walls without introducing excessive stress, the wall thickness could be reduced, and thereby increase the test section volume. Solid insulants would also limit the rate at which sodium could be flooded into the gap. Furthermore, the particular material may not be compatible with sodium even for the relatively short time necessary to remove decay heat from the loops. If an insulation gap filler could be found to provide a much lower thermal conductivity for a $1 / 8$ in. gap than is necessary, the gap width could be reduced, again increasing the space available for test section enlargement.

\section{EXPERIMENTAL VERIFICATION AND EVALUATION}

The effective thermal conductivity of the insulated tube for the materials selected can most accurately be determined by experimental data. An analysis based on known thermal conductivity values and heat transfer principles will, at best, yield a good estimate. Variables or indeterminates that add to the inaccuracy of an analysis include the following: the contribution to heat transfer by the gap spacers, attainment and maintenance of surface emissivity on a given material under simulated operating conditions, and the thermal conductivity for a $1 / 8$ in. thickness of a given material as used in a closed loop tube structure (the manufacturers suggested values are based on a thicker specimen). 


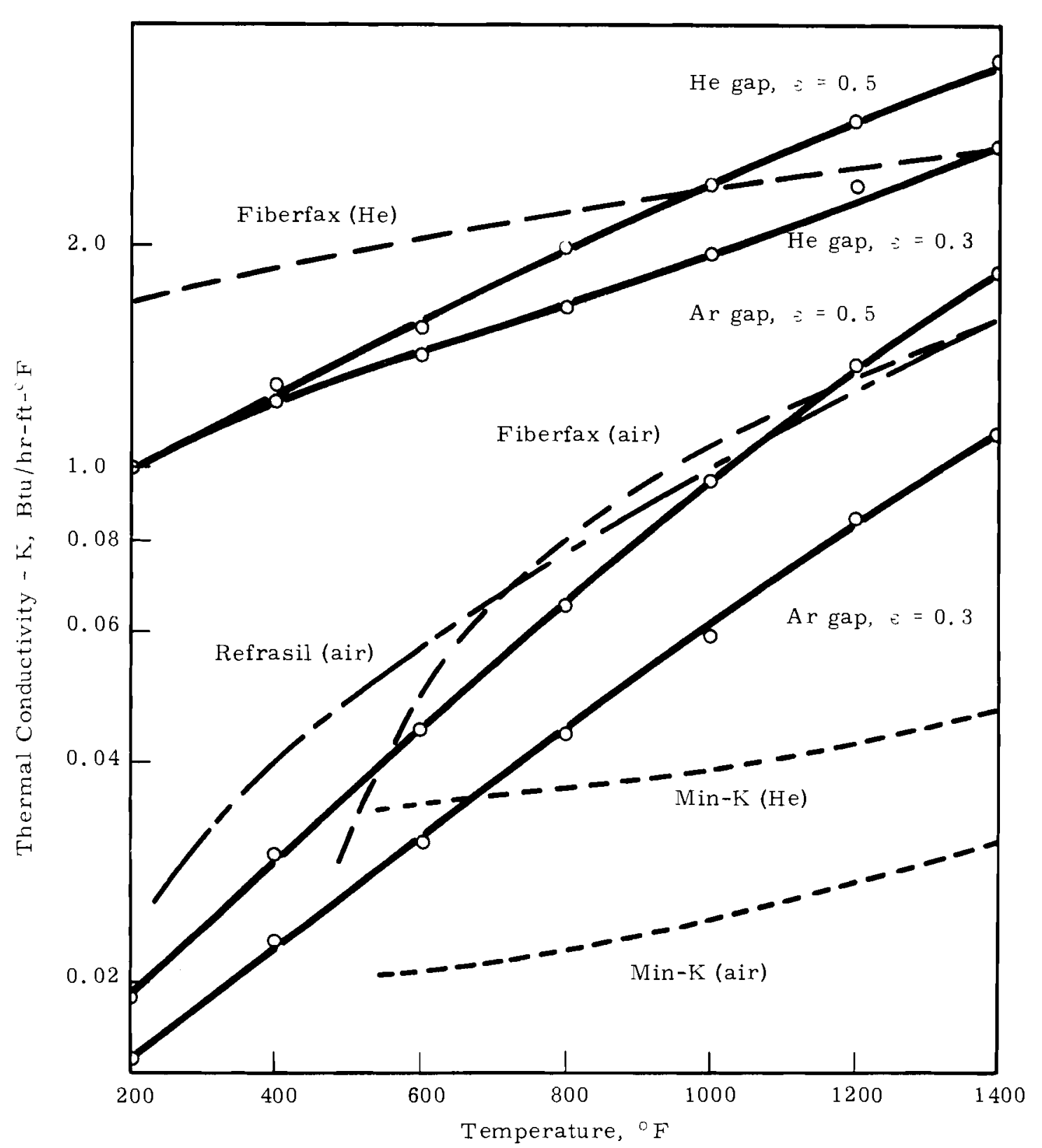

FIGURE 4. Thermal Conductivity Versus Temperature for Several Insulation Gap Fillers 
The selection of a spacer configuration will require consideration of the added heat transfer, local temperature gradients, attachment method, and differential wall expansion effects. Little information is available concerning the techniques for polishing 316 or 304 SS to obtain a low emissivity. Since the alloy content is a critical variable, methods used to produce the emissivity values given in Reference 16 and 17 may not be applicable to the alloys used in the closed loop tubes. Maintaining a given emissivity through several thermal cycles, and at elevated temperatures, will require a relatively inert atmosphere. That is, the degree of gas purity required must be determined. The need for spacers with solid materials must be determined prior to experimental verification of thermal conductivity of the insulated tubes. The spacer design may or may not differ when used in smaller gap widths with or without solid insulants.

The twin wall tube using an annular insulation gap requires development work in the following areas for final design:

- Determination of the insulation effectiveness provided by the selected structure under various simulated reactor operating conditions, gas (or vacuum) quality, and tube surface emissivity.

- Experimental verifications of structural adequacy, particularly in maintaining a uniform insulating gap by spacers or other means and avoiding hot spots that could produce tube distortion or excessive thermal stresses.

- Experimental verification of slip joint, bellows, or other design to accommodate relative movement between the inner and outer tube walls and spacers (including limiting stresses, galling, fretting, etc.).

- Prototype closed loop tube assembly testing. 


\section{REFERENCES}

1. FFTF Progress Report, BNWL-470, Pacific Northwest Laboratory, Richland, Washington. August 1967.

2. S. Timoshenko and J. N. Goodier. Theory of Elasticity, 2nd ed., p. 414, McGraw Hill Book Co. 1951.

3. R. C. Aungst. Letter to D. R. Doman, Fabrication of Insulated Closed Loop Tubes. December 1966.

4. W. C. Townsend. Letter to D. R. Doman, Cylindrical Process Tube Thermal FFTF Stress Analysis. November 1966.

5. K. L. Smith and D. Caple. Development of Solid-Insulated Pressure Tubes for Candu-Type Reactors, Atomic Energy of Canada Limited, AECL-1692, February 1963.

6. P. A. Ross-Ross and K. L. Smith. Pressure-Tube Development for Canada's Power Reactors. An ASME Publication 64-WA/NE-5, September 14, 1964.

7. W. M. Campbell. A Current Assessment of the OrganicCooled Heavy-Water Moderated Reactor, Atomic Energy of Canada Limited, AECL-1692, February 1963.

8. D. G. Boxall, W. M. Brown, D. B. Nazzer, J. T. Rogers, R. G. Hart, and K. L. Smith. Development of Fuel and Coolant Tubes for a Reactor Cooled by Organic Liquid. Papers Presented by Canada to the Third U. N. International Conference on the Peaceful Uses of Atomic Energy, Geneva, August 31 to September 9, 1964. AECL-2023.

9. French Patent 1,321, 767, February 11, 1963. Nuclear Power Plant (to Sulzer Freres S. A.). Priority data June 26, 1961, Switzerland.

10. German Patent 1, 201, 927. Double-Walled Pressure Tube for a Nuclear Reactor. Baron Pierre Georges (to Groupement Atomique Alsacienne Altantique). September 30, 1965. Priority date July 30, 1962, France.

11. P. J. Pankaskie and R. H. Purcell. Personal Communication. Pacific Northwest Laboratory, Richland, Washington.

12. R. F. MacPherson, Jr. and H. D. Stuart. "The Performance of Metallic Foil Insulations in Vertical Gas Spaces, "Nuclear Science and Engineering, vol. 12, pp. 225-233. 1962.

13. P. M. Jackson and D. C. Schmale. Personal communication. Pacific Northwest Laboratory, Richland, Washington. March 18, 1968. 
14. The FFTF Design Study Phase II Final Report, WCAP 3684-4, Westinghouse Electric Co. February 1967.

15. Final Report for FFTF Design Review and Alternate Concept Studies, Ido - 17181, Phillips Petroleum Company. April 29, 1966.

16. Frank Kreith. Principles of Heat Transfer, 2nd ed. Scranton, Pennsylvania, International Textbook Company. 1966.

17. W. H. McAdmas. Heat Transmission, 3rd ed. McGraw Hill Book Company, Inc. 1954.

18. M. L. Minges, 1st. Lt. USAF. Thermal Insulations for Aerospace Applications -423 to $+3000^{\circ} \mathrm{F}$, Technical Documentary Report No. A.SD-TDR-63-699. September 1963.

19. W. F. Brunner, Jr. and T. H. Batzer. Practical Vacuum Techniques, Reinhold Publishing Co., New York. 1965.

20. "Thermophysical Properties Research Center, "Nonmetallic Elements Compounds and Mixtures, vol. 2, Purdue University, Lafayette, Indiana.

21. D. R. Doman. Requirements and Selection of Insulation Applicable to the ATR Test Section, HW-79336, General Electric Company. October 1963.

22. D. R. Doman. "Fabrication Techniques, " Cast Fiberfrax Insulation for the Model High Temperature Gas Loop, HW-81075, Generai Electric Company. March 1964. 
BNWL-755

APPENDICES 


\section{A. 1}

BNWL-755

\section{APPENDIX A \\ RESULTS OF INSULATED TUBE STUDIES}

The results of insulated tube studies performed by Hawker Siddeley and Canadian General Electric ${ }^{(5-8)}$ relating to the closed loop tube insulation problem are presented as follows.

Tube I was constructed with the liner tube external to the stress tube; "Refrasil" and 80 mesh compacted Silica sand provided the insulation material. The ends of the tube were rigidly clamped such that they would expand and contract together. The clamps also provided parts for internal stress tube heating, insulation gap pressure monitoring, and vacuum pressure lines.

The first 50 thermal cycles were used to evaluate the tube at the thermal stress level expected in a Zircaloy-2 tube construction operating at typical CANDU conditions. Since the tube showed no signs of instability, the stress tube temperature was increased each cycle. After the pressure was released on cycle 77, a diamond stress pattern, probably due to buckling, appeared on the surface of the liner tube. The stress tube had reached $510^{\circ} \mathrm{F}$, and the liner tube was at $181^{\circ} \mathrm{F}$, or a $329^{\circ} \mathrm{F}$ temperature difference had been imposed on the tube.

Results of the test also indicated a permanent elongation of the liner tube of $0.03 \%$ with no evidence of insulation deterioration. In addition, the thermal conductivity was determined for insulation gap pressures of 0 and $29 \mathrm{in} . \mathrm{Hg}$, and a $\Delta \mathrm{T}$ of 74 and $326^{\circ} \mathrm{F}$.

Tubes II, III, and IV were constructed with Zircaloy-2 stress tubes, Min- $\mathrm{K}$ insulation ( 6 in. long, $120^{\circ}$ cast sections), and either SAP-895 or Zircaloy-2 external liner tubes. The stress tube and liner tube were rigidly attached at each end by forming a rolled joint. Thermal cycling exposed these tubes to a $645^{\circ} \mathrm{F}$ temperature difference by maintaining the stress tube cooling water temperature at 70 to $80^{\circ} \mathrm{F}$ while thermally cycling the liner tube to a maximum of $725^{\circ} \mathrm{F}$. 
The liner tube in Tube II and the stress tube in Tube III were unstable in axial compression. The change in unstable member from liner to stress tube indicates the importance of liner/stress tube thickness ratio, and furthermore, the ratios used bracketted the optimum for the materials used. Reference 8 indicates that the thermal conductivity of the Min-K material was not adversely affected by the thermal cycling. Tube IV was identical to Tubes II and III except that the liner tube was Zircaloy-2 and the stress/liner tube wall thickness ratio was $1 / 1$. Thermal cycling results indicate slight liner tube wrinkles and joint leakage, and consequently the tube was not of reactor quality.

Table A. 1 summarizes the Hawker Siddeley and Canadian General Electric results. 
TABLE A. 1. Related Insulated Tube Studies Data

\begin{tabular}{|c|c|c|c|c|c|}
\hline \multirow[b]{2}{*}{ Description } & \multirow[b]{2}{*}{$\stackrel{\text { I }}{\text { Hawker Siddeley }}$} & \multicolumn{4}{|c|}{ Tube Identification } \\
\hline & & $\begin{array}{r}\text { II } \\
\# 4-10\end{array}$ & 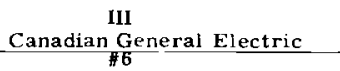 & IV & $\begin{array}{l}V \\
\text { Closed Loops }\end{array}$ \\
\hline $\begin{array}{l}\text { Stress Tube OD, in } \\
\text { Wall Thickness, in. } \\
\text { Material }\end{array}$ & $\begin{array}{r}\begin{array}{r}3.305 \\
0.090 \\
4130 \text { Steel }\end{array} \\
4\end{array}$ & - & $\begin{array}{l}\text { 3. } 640 \\
\text { Ory-2 }\end{array}$ & $\begin{array}{l}3.644 \\
0.031 \\
\text { Zry-2 }\end{array}$ & $\begin{array}{l}0.10 \text { to } 0.150 \\
304 \mathrm{SS}\end{array}$ \\
\hline Insulation Thickness. in. & $\begin{array}{l}0.034 \text { Refrasil } \\
0.048 \text { Silica Sand }\end{array}$ & $\underset{M i n-K}{0.087}$ & $\underset{\text { Min-K }}{0.085}$ & $\begin{array}{c}\mathbf{0 . 0 8 6} \\
\text { Min-K }\end{array}$ & $\begin{array}{l}0.125 \\
?\end{array}$ \\
\hline $\begin{array}{l}\text { Liner Tube OD, in. } \\
\text { Thickness, in. } \\
\text { Material }\end{array}$ & $\begin{array}{c}3.5 \\
0.016 \\
321 \mathrm{SS} \\
\text { External }\end{array}$ & $\begin{aligned} & 3.372 \\
& 0.062 \\
& \text { SAP-895 } \\
& \text { Internal }\end{aligned}$ & $\begin{array}{r}3.370 \\
0.060 \\
\text { SAP-895 } \\
\text { Internal }\end{array}$ & 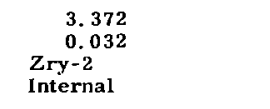 & $\begin{array}{l}0.10 \text { to } 0.150 \\
304 \mathrm{SS}\end{array}$ \\
\hline Specimen Length, in. & 36 & $1137 / 8$ & 100.9 & 114 & \\
\hline $\begin{array}{l}\text { Liner/Stress Tube Wall } \\
\text { Thickness Ratio }\end{array}$ & & $2 / 1$ & $3 / 1$ & $1 / 1$ & \\
\hline Internal Pressure, psi & 1500 & 300 & 300 & 300 & $250+$ \\
\hline \multirow[t]{5}{*}{ Thermal Cycles } & Liner Temperature & \multicolumn{2}{|c|}{$\begin{array}{l}\text { Stress Tube Cooling Water Maintained at } 70 \text { to } 80^{\circ} \mathrm{F} \text {. } \\
\text { Cycles on Liner Tube as Indicated Below: }\end{array}$} & Number of Thermal & \\
\hline & 60 to $90 \circ \mathrm{F}$ & $\begin{array}{r}20 \\
130 \\
\end{array}$ & $\begin{array}{r}7 \\
124\end{array}$ & $\begin{array}{l}20 \text { at } 70 \text { to } 725^{\circ} \mathrm{F} \\
208 \text { at } 200 \text { to } 725^{\circ} \mathrm{F}\end{array}$ & \\
\hline & $\begin{array}{l}\text { Pressure tube, } 50 \text { cycles } \\
\text { at } 80 \text { to } 150{ }^{\circ} \mathrm{F}\end{array}$ & 150 & 131 & 228 & \\
\hline & $\begin{array}{l}\text { 72nd cycle-liner } 54 \text { to } 126^{\circ} \mathrm{F} \\
\text { Pressure tube } 70 \text { to } 270\end{array}$ & & & & \\
\hline & $\begin{array}{l}\text { 77th cycle-liner } 61 \text { to } 1811^{\circ} \mathrm{F} \\
\text { Pressure tube } 70 \text { to } 510^{\circ} \mathrm{F}\end{array}$ & & & & \\
\hline $\begin{array}{l}\text { Thermal Conductivity } \\
\left(\mathbf{B t u} / \mathrm{hr} \mathbf{r}-\mathrm{ft}^{\circ} \mathrm{F}\right)\end{array}$ & $\begin{array}{l}0.045 \text { at } 74{ }^{\circ} \mathrm{F}, \quad 0 \text { in. } \mathrm{Hg} \\
0.173 \text { at } 326{ }^{\circ} \mathrm{F}, 0 \text { in. } \mathrm{Hg}\end{array}$ & & & & \\
\hline & $\begin{array}{l}0.135 \text { at } 74{ }^{\circ} \mathrm{F}, 29 \text { in. } \mathrm{Hg} \\
0.206 \text { at } 326{ }^{\circ} \mathrm{F}, 29 \text { in. } \mathrm{Hg}\end{array}$ & & & & \\
\hline$\Delta T$ Maximum, ${ }^{\circ} \mathrm{F}$ & 329 & 645 & 645 & 645 & $400+$ \\
\hline Total Wall Thickness, in. & 0.1795 & 0.199 & 0.195 & 0.167 & 0.425 \\
\hline $\begin{array}{l}\text { Coefficient of Thermal Expansion, } \\
\left(\mu \text { in. / in. } /{ }^{\circ} \mathrm{F}\right)\end{array}$ & $\begin{array}{l}4130 \text { Steel } 6.5 \\
321 \text { Steel } 9.3\end{array}$ & Zry-2 $3^{(a)}$ & $Z$ ry-2 $3^{(a)}$ & SAP-895, $12^{(a)}$ & $304 \mathrm{SS}, \quad 9.9^{(a)}$ \\
\hline $\begin{array}{l}\text { Moduluss of Flasticity } \\
\left(10^{-6} \mathrm{psi}\right)\end{array}$ & $\begin{array}{l}4130 \text { Steel } \\
29^{(a)} \text { at } 510 \text { o } \\
321 \text { Steel } \\
28^{(a)} \text { at rom temperature }\end{array}$ & $\begin{array}{l}\text { SAP-895, } \\
10.6 \text { at } 700^{\circ} \\
\text { Zrry-2 (cold worked) } \\
13.43 \text { at } 70 \text { to } 2000^{\circ}\end{array}$ & $\begin{array}{l}\text { SAP-895, } \\
10.6 \text { at } 70{ }^{\circ} \mathrm{F} \\
Z_{\text {ry-2 (cold worked) }} \text { (cold } \\
13.43 \text { at } 70 \text { to } 200^{\circ} \mathrm{F}\end{array}$ & $\begin{array}{l}\text { Zry-2, } 10.5 \\
\text { at } 700{ }^{\circ}{ }^{\circ}(a)\end{array}$ & $\begin{array}{l}304 \mathrm{SS} \\
28^{(a)} \text { at room temperature } \\
24^{(\text {a) }} \text { at } 1200^{\circ} \mathrm{F}\end{array}$ \\
\hline Yield Stress $\left(10^{-3} \mathrm{psi}\right)$ & $\begin{array}{l}4130 \text { Steel } \\
\left.100^{\text {Sal }}\right)_{\text {at }} 510^{\circ} \mathrm{F}\end{array}$ & $\begin{aligned} \mathrm{SAP}-895, & 32 \text { at } 70{ }^{\circ} \mathrm{F} \\
14.9 \text { at } & 700^{\circ} \mathrm{F}\end{aligned}$ & $\begin{array}{r}\mathrm{SAP}-895, \quad 32 \text { at } 70^{\circ} \mathrm{F} \\
14.9 \text { at } 700^{\circ} \mathrm{F}\end{array}$ & $Z_{r y}-2,75$ at $70^{\circ} \mathrm{F}$ & ${ }_{35}^{304}(\mathrm{a} S)$ at room temperature \\
\hline & $\begin{array}{l}321 \text { Steel } \\
35(a) \text { at room temperature }\end{array}$ & $\mathrm{Zry}-2,62$ at 70 to $200^{\circ} \mathrm{F}$ & Zry-2, 62 at 70 to $200^{\circ} \mathrm{F}$ & Zry-2, 28 at $700^{\circ} \mathrm{F}$ & $10^{(a)}$ at $1200^{\circ} \mathrm{F}$ \\
\hline$\underline{E_{\Delta \Delta T}}$ & $\begin{array}{l}321 \text { Steel } 2.45 \text { at room } \\
\text { temperature }\end{array}$ & Zry-2, 0.3455 at $70^{\circ} \mathrm{F}$ & $Z$ ry $-2,0.3455$ at $70^{\circ} \mathrm{F}$ & & \\
\hline Yield Stress & 4130 Steel 0.62 at $510^{\circ} \mathrm{F}$ & $\begin{array}{r}0.726 \text { at } 700^{\circ} \mathrm{F} \\
\text { SAP-895, 3.98 at } 700^{\circ} \mathrm{F}\end{array}$ & $\begin{array}{r}0.726 \text { at } 700^{\circ} \mathrm{F} \\
\text { SAP-895, } 3.98 \text { at } 700^{\circ} \mathrm{F}\end{array}$ & & $\begin{array}{l}304 \mathrm{SS} \\
9.5 \text { at } 1200^{\circ} \mathrm{F}\end{array}$ \\
\hline
\end{tabular}



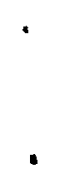

. 


\section{APPENDIX B}

PROPERTIES OF SOLID INSULANT MATERIALS APPLICABLE TO THE CLOSED LOOP TUBES:* TABLE B. 1 AND FIGURE B. 1.

* This information was taken from Doman's $(21,22)$ reports and revised. 
TABLE_... 1. Properties of Various Commercialiy Available Insulation Materials Applicable to the Closed Loop Tubes

Note: The manulacturers have made specific clains for their materials in this particular usage. Infurmation given here is not to be consirued that any product is superior to another in general usage, nor do the results indicate periormance under any condition other than here specified.

\begin{tabular}{|c|c|c|c|c|c|c|c|c|}
\hline Trade Name & Manufacturer & Type & Composition & $\begin{array}{l}\text { A pprox Bulk } \\
\text { Density, } \\
-1 \mathrm{~b} / \mathrm{ft}^{3} \\
\end{array}$ & $\begin{array}{l}\underline{\mathrm{K}}_{\text {bulk }} \text { at } 1600^{\circ} \mathrm{F} \\
\quad \text { In Air } \\
\quad(1 \text { atm }) \\
\end{array}$ & $\begin{array}{c}\mathrm{Btu} / \mathrm{hr}-\mathrm{ft}-{ }^{\circ} \mathrm{F} \\
\mathrm{InHe} \\
\left(300 \mathrm{psia}^{(a)}\right)\end{array}$ & $\begin{array}{l}\text { T max for con- } \\
\text { tinuous use in air } \\
\text { and He, }{ }^{\circ} \mathbf{F}\end{array}$ & $\begin{array}{c}\text { Limitations } \\
\text { of this } \\
\text { Application } \\
\end{array}$ \\
\hline Fiberírax & Carborundum & $\begin{array}{l}\text { Blanket } \\
\text { (Long Fiber) }\end{array}$ & $\mathrm{Al}_{2} \mathrm{O}_{3}+\mathrm{SiO}_{2}$ & 6 & 0.196 & 0.285 & 2300 & $4,5,7,8$ \\
\hline Fiberfrax & Carborundum & Cast (Porous) & $\mathrm{Al}_{2} \mathrm{O}_{3}+\mathrm{SiO}_{2}$ & 24 & 0.115 & 0.275 & 2300 & 7,8 \\
\hline Cerafelt & Johns-Manville & Felt, Fibrous & $\mathrm{Al}_{2} \mathrm{O}_{3}+\mathrm{SiO}_{2}$ & 3 to 24 & 0.15 & 0.285 & 2300 & $4,5,7,8$ \\
\hline Dyna Quartz & Johns-Manville & Felt, Fibrous & $\mathrm{SiO}_{2}$ & 4.5 to 10.0 & 0.086 & 0.215 & 2750 & $4,5,7,8,10$ \\
\hline Micro Quartz & $\begin{array}{l}\text { Johns-Manville and } \\
\text { Libby-Owen Ford }\end{array}$ & $\begin{array}{l}\text { Blanket, } \\
\text { Fibrous }\end{array}$ & $\mathrm{SiO}_{2}$ & 3 to 9 & 0.121 & 0.215 & 2000 & $4,5,7,8$ \\
\hline Refrasil & H. I. Thompson & Fiber & $\mathrm{SiO}_{2}$ & 3 to 9 & 0.205 & 0.215 & 2000 & $4,5.7,8$ \\
\hline $\begin{array}{c}\text { Carbon and Graphite } \\
\text { Felt }\end{array}$ & $\begin{array}{l}\text { Nat'l Carbon and } \\
\text { Great Lakes Carhon } \\
\text { Co. }\end{array}$ & Felt, Fibrous & Carbon & 7 & Oxidizes & 0.10 & $\begin{array}{l}4750 \mathrm{He}, \\
\text { oxidizes in } \\
\text { air }\end{array}$ & $4,5,7,8,9$ \\
\hline Min-K & Johng-Manville & Molded & $\begin{array}{l}\text { Silica-A sbestos- } \\
\text { Metal Clad }\end{array}$ & 14 to 20 & 0.038 & 0.15 & 1850 & $8,10.14$ \\
\hline $\mathrm{Min}-\mathrm{K}$ & Johng-Manville & $\begin{array}{l}\text { Fibrous, Metal } \\
\text { Clad }\end{array}$ & $\begin{array}{l}\text { Silica-A sbestos } \\
\text { Clad }\end{array}$ & 14 to 20 & $\begin{array}{l}0.038 \\
\text { For insulation } \\
\text { only }\end{array}$ & $\begin{array}{l}0.15 \\
\text { For insulation } \\
\text { only }\end{array}$ & unknown & $1,8.10 .12 .14$ \\
\hline Tipersul & du Pont & Fiberous, Cast & $\mathrm{K}_{2} \mathrm{TiO}_{3}$ & 3 to 72 & 0.074 & 0.2 & 2100 & $\begin{array}{l}\text { 4. } 5.8 .10,11 . \\
\text { (fibrous) }\end{array}$ \\
\hline Zircoa & $\begin{array}{l}\text { Zirconium Corp. } \\
\text { of America }\end{array}$ & Cast & $\mathrm{ZrO}_{2}$ & 265 & 0.63 & 0.86 & 4600 & $2,8,10,11,1 ;$ \\
\hline Silicon & Carborundum & Porous SiC & $\mathrm{SiC}$ & $\begin{array}{l}\text { Low density } \\
0.17 \\
\text { high density } \\
0.35\end{array}$ & $\begin{array}{l}\text { low density } \\
0.57 \\
\text { high density } \\
1.1\end{array}$ & $\begin{array}{l}2.6 \\
4.1\end{array}$ & $\begin{array}{l}4000 \mathrm{He} \\
3000 \mathrm{Air}\end{array}$ & 2.6 .8 .10 .14 \\
\hline Cercor & Corning Glass & Cast & Pyroceramic & 30 & 0.034 & unknown & 2012 & $3,6,10,14$ \\
\hline $\begin{array}{l}\text { Solami } \\
\text { (Corrugated Foil) }\end{array}$ & $\begin{array}{l}\text { Solar Aircraft } \\
\text { Div. Intern'l Harvester }\end{array}$ & Metallic & Inconel 600 & 40 & unknown & $\begin{array}{l}0.36 \\
0.45\end{array}$ & 2150 & $2,3,10$ \\
\hline Separated Flat Foil & Hawker-Siddeley, Inc. & Metallic Foil & Inconel 600 & 20 & unknown & 0.54 & 2150 & $2,3,10$ \\
\hline Thermaflex & Johns-Manville & Felt & $\mathrm{Al}_{2} \mathrm{O}_{3}+\mathrm{SiO}_{2}$ & 3 to 24 & 0.15 & 0.285 & 2300 & $4,8,12,14$ \\
\hline Kaowool & Babcock and Wilcox & Blanket, Fibrous & $\mathrm{Al}_{2} \mathrm{O}_{3}+\mathrm{SiO}_{2}$ & 3 to 10 & 0.285 & unknown & 2012 & $4,5,8,14$ \\
\hline
\end{tabular}

(a) Thermal conductivities in helium are calculated and extrapolated values only; experimental testing could change the values significantly.

1. Maximum continuous operating temperature too low or marginal.

2. Relatively high thermai conductivity.

Not readily formed into mode rately
reducers, and internal cavities.

Not self-supporting.

Encasement necessary to retain required dimensions.

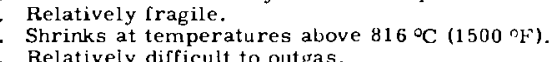

9. Possibility of chemical or metallurgical reaction with hot inner pipe.
10. Pelatively high priced (compared with cast Fiberfrax as hase).

12. High density, may give gamma heating problems in core.

12. High density, may give ga 


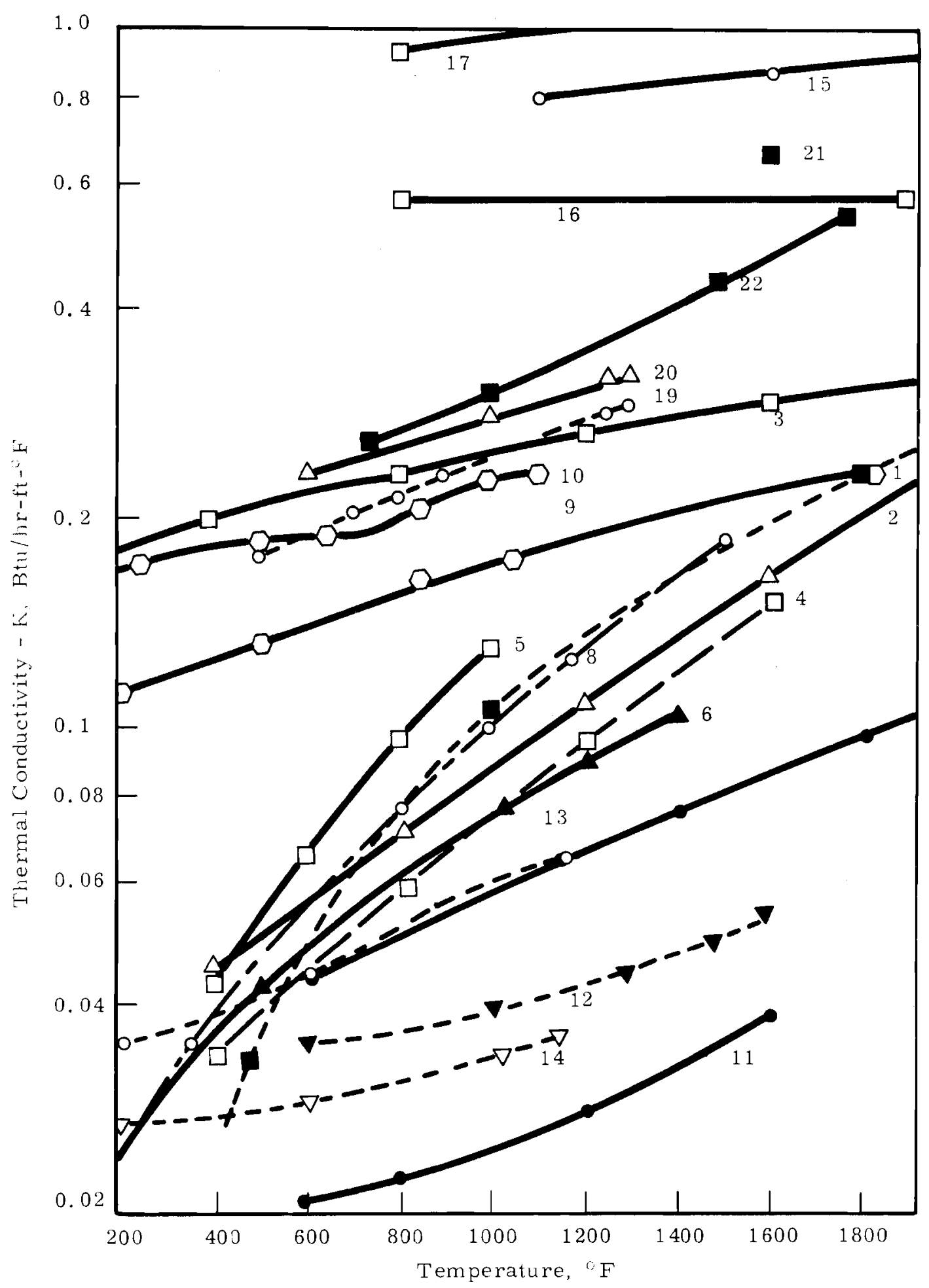

FIGURE B.1. Thermal Conductivity Versus Temperature for Several Solid Insulant Materials 
LEGEND TO FIGURE B. 1

(Values in Air Except Where Noted)

1. Fiberfrax Blanket (long fiber), $6 \mathrm{lb} / \mathrm{ft}^{3}$

2. Castable Fiberfrax, $24 \mathrm{lb} / \mathrm{ft}^{3}$

3. Fiberfrax Blanket, long fiber (in helium), $6 \mathrm{lb} / \mathrm{ft}^{3}$

4. Cerafelt and Thermoflex (insulation only), $6 \mathrm{lb} / \mathrm{ft}^{3}$

5. Kaowool bulk fibers, $3 \mathrm{lb} / \mathrm{ft}^{3}$

6. Micro Quartz, $3 \mathrm{lb} / \mathrm{ft}^{3}$

7. Dyna-Quartz, 6.2 lb/ft ${ }^{3}$

8. Refrasil, $3 \mathrm{lb} / \mathrm{ft}^{3}$

9. $\mathrm{SiO}_{2}$ (in helium), $3 \mathrm{lb} / \mathrm{ft}^{3}$

10. Carbon Felt (in helium) Los Alamos Data

11. Min-K \#2000 Molded Insulation, $20 \mathrm{lb} / \mathrm{ft}^{3}$

12. Min-K \#2000 Molded Insulation, (in helium), $20 \mathrm{lb} / \mathrm{ft}^{3}$

13. Tipersul, $3.41 \mathrm{~b} / \mathrm{ft}^{3}$

14. Tipersul, $71.5 \mathrm{lb} / \mathrm{ft}^{3}$

15. $\mathrm{ZrO}_{2}$ (helium), $265 \mathrm{lb} / \mathrm{ft}^{3}$

16. SiC foam low density

17. SiC foam, high density (in helium)

18. Cercor

19. 17.0 psia Solami Metallic insulation, Solar data (in helium)

20. 314.3 psia Solami Metallic insulation, Solar data (in helium)

21. Hawker-Siddeley Metallic Foil (in helium)

22. Solami, Los Alamos Data 


\section{DISTRIBUTION}

No. of

Copies

OFFSITE

AEC Chicago Patent Group

G. H. Lee, Chief

AEC Division of Technical Information Extension

1 AEC Idaho Operations Office

Nuclear Technology Division

C. W. Bills, Director

AEC Library, Washington

M Shaw, Director, RDT

Asst Dir for Nuclear Safety

Analysis \& Evaluation Br, RDT:NS

Environmental \& Sanitary Engrg Br, RDT:NS

Research \& Development Br, RDT:NS

Asst Dir for Plant Engrg, RDT

Applications \& Facilities Br, RDT:PE

Components $\mathrm{Br}$, RDT:PE

Instrumentation \& Control Br, RDT: PE

Liquid Metals Systems Br, RDT:PE

Asst Dir for Program Analysis, RDT

Asst Dir for Project Mgmt, RDT

Liquid Metals Projects Br, RDT:PM

FF'TF Project Manager, RDT:PM (3)

Asst Dir for Reactor Engrg

Control Mechanisms Br, RDT:RE

Core Design Br, RDT:RE (2)

Fuel Fabrication Br, RDT:RE

Fuel Handling $\mathrm{Br}, \mathrm{RDT}$; RE

Reactor Vessels Br, RDT:RE

Asst Dir for Reactor Tech

Coolant Chemistry, RDT

Fuel Recycle Br, RDT

Fuels \& Materials Br, RDT:RT

Reactor Physics Br, RDT:RT

Special Technology Br, RDT:RT

Asst Dir for Engrg Standards

AEC San Francisco Operations Office

Director, Reactor Division 
No. of Copies

4

AEC Site Representatives

Argonne National Laboratory

Atomics International

Atomic Power Development Assoc.

General Electric Co.

2

Argonne National Laboratory

R. A. Jaross

LMFBR Program Office

8

Atomics International

D. J. Cockeram (5)

R. W. Dickinson Liquid Metal Engrg Center

Atomic Power Development Assoc.

Document Librarian

Babcock \& Wilcox Co.

Atomic Energy Division

S. H. Esleeck

G. P. Garton

Bechtel Corporation

J. J. Teachnor, Project Administrator

1 Combustion Engineering

1000 MWe Follow-On Study

W. P. Staker, Project Manager

3

Douglas United Nuclear

$47 \quad$ Fast Reactor Exchange

2 Gulf General Atomic Inc.

General Atomic Div.

D. Coburn

$5 \quad$ General Electric Co.

Advanced Products Operation

Karl Cohen (3)

Bertram Wolfe

Nuclear Systems Programs

D. H. Ahmann 
No. of

Copies

1 Idaho Nuclear Corp.

D. R. de Boisblanc

1 PNL Representative

N. A. Hill (ZPR III)

$1 \quad$ Stanford University

Nuclear Division

Division of Mechanical Engrg

R. Sher

$1 \quad$ United Nuclear Corp.

Research and Engineering Center

R. F. DeAngelis

10 Westinghouse Electric Corp.

Atomic Power Division

Advanced Reactor Systems

J. C. R. Kelly

ONSITE - HANFORD

1

A EC Chicago Patent Group

R. K. Sharp

5

AEC Richland Operations Office

FFTF Program

J. M. Shivley (3)

C. L. Robinson

Technical Information Library

$4 \quad$ AEC Site Representatives - PNL

P. G. Holsted (2)

L. R. Lucas

A. D. Toth

$3 \quad$ Battelle Memorial Institute

1 Bechtel Corporation

D. H. Weiss

1 Westinghouse Electric Corp.

R. Strzelecki 
No. of

Copies

Battelle-Northwest

S. O. Arneson

E. R. Astley

R. C. Aungst

J. M. Batch

T. Bauman

J. D. Berg

C. L. Boyd

D. C. Boyd

C. M. Cantrell

J. R. Carrell

W. E. Cawley

D. L. Condotta

J. M. Davidson

V. A. Deliso

R. V. Dulin

E. A. Evans

L. M. Finch

E. E. Garrett

S. M. Gill

R. J. Hennig

P. L. Hofmann

B. M. Johnson

H. G. Johnson

R. N. Johnson

R. S. Kemper

W. C. Kinsel

R. L. Knecht (5)

J. W. Kolb

R. Kolowith
C. E. Leach

C. E. Love

M. K. Mahaffey

W. B. McDonald

C. A. Munro

C. R. Nash

C. L. Peckinpaugh

R. E. Peterson

O. W. Priebe

F. B. Quinlan

W. E. Roake

G. R. Sawtelle (5)

F. H. Shadel

D. E. Simpson

E. B. Schwenk

R. J. Squires

C. D. Swanson

J. C. Tobin

K. G. Toyoda

M. A. Vogel

R. C. Walker

J. H. Westsik

R. G. Wheeler (5)

N. G. Wittenbrock

L. A. Whinery

F. W. Woodfield

FFTF File (5)

Technical Information Files (5)

Technical Publications (2) 